\title{
Proline and Antioxidant Enzyme Activities in Some Strawberry Cultivars under Drought and Recovery
}

\author{
Hatice GULEN ${ }^{1 *}$, Muge KESICI ${ }^{1}$, Cem CETINKAYA ${ }^{2}$, Sergul ERGIN ${ }^{3}$ \\ ${ }^{1}$ Istanbul Bilgi University, Faculty of Engineering and Natural Sciences, Department of Genetics and Bioengineering, Santral Istanbul Campus, \\ 34060 Eyup,Istanbul,Turkey; hatice.gulen@bilgi.edu.tr (*correspondingauthor);muge.kesici@engr.bilgi.edu.tr \\ ${ }^{2}$ Uludağ University, Faculty of Agriculture, Department of Horticulture, Gorukle Campus, 16059 Nilufer, Bursa, Turkey; cctnky@gmail.com \\ ${ }^{3}$ Eskisehir Osmangazi University, Faculty of Agriculture, Department of Agricultural Biotechnology, Ali Numan Kirac Campus, 26160, \\ Eskisehir,Turkey; ergins@esogu.edu.tr
}

\begin{abstract}
This study examines the molecular effects of drought and recovery applications on four strawberry (Fragaria $\times$ ananassa Duch) cultivars known as relatively heat-tolerant ['Redlands Hope' ('R. Hope') and 'Camarosa'] and heat-sensitive ['Festival' and 'Cal. Giant-3' ('CG-3')]. After frigo seedlings were grown in a greenhouse for eight weeks (until they had five-six leaves) in a pot, 10\% Poliethyleneglycol 6000 (PEG) was applied in order to compose drought condition for 15 days. Following PEG application, plants were watered without PEG for 15 days to observe the recovery. Leaf relative water content (RWC), loss of turgidity, cell membrane injury, proline content and the activities of ascorbate peroxidase (APX, EC 1.1.11.1), glutathione reductase (GR, EC 1.6.4.2) and peroxidase (PRX, EC 1.11.1.7) were determined in leaf tissues taken from plants at the end of the drought and recovery applications. Although membrane injury was increased by the PEG application, it reduced almost to the control levels at the end of the recovery period. Proline contents were found higher in cvs. 'R. Hope' and 'Camarosa' than cvs. 'Festival' and 'CG-3' under drought conditions. APX and GR enzymes showed great activities in drought applied plants of heat-tolerant cultivars. Native polyacrylamide gel electrophoresis (PAGE) of basic PRX isozymes yielded three protein bands with $R f=0.45, R f=0.55$ and $R f=0.60$ that were sharply increased their activities by PEG and recovery applications in cvs. ' $R$. Hope' and 'Camarosa'. In addition, leaves of all cultivars exposed to drought rolled up and had brown colour in various level as an indication of tolerance. Indeed 'Camarosa' and 'R. Hope' showed better recovery performance after rewatering than 'Festival' and 'CG-3'. All data indicated that heat-tolerant cultivars showed relatively drought tolerance in this study.
\end{abstract}

Keywords: antioxidative enzymes; drought; Fragaria $\times$ ananassa Duch; PEG; recovery

\section{Introduction}

According to the climatic change models, extreme climatic events is predicted in next decades (IPCC, 2014). Therefore, plants are exposed to various supraoptimal conditions during their life cycles as a result of open-field growing. Poliethyleneglycol (PEG) is a neutral polymer used to impose water stress by exposing the root system of plants and PEG 6000, with its medium molecular weight, is preferred for it's better to work with plants (Ming et al., 2012; Grzesiak et al., 2013). But with the rewatering, recovery of plant growth and photosynthesis would appear immediately through growing new plant parts and decreasing peroxidation ( $\mathrm{Xu}$ et al., 2010). In this sense, electrolyte leakage is an effective means of measuring cell membrane thermostability and has been used as an indicator of direct membrane injury in many stresses (Gulen and Eris, 2004; Gulen et al., 2008; Kesici et al., 2013). Stress-induced reactive oxygen species (ROS) cause lipid peroxidation and therefore membrane injuries, protein degradation, enzyme inactivation can be seen in cellular level (Sairam et al., 2005). As a free radical scavenger proline also acts and may be more important in overcoming stress than in acting as a simple osmolyte (Reddy et al., 2004; Verslues and Bray, 2006). Plants exposed to drought stress can overcome with oxidative stress via activation of some or all the antioxidant enzymes (Srivalli et al., 2003; Jung, 2004). Detoxification of hydrogen peroxide $\left(\mathrm{H}_{2} \mathrm{O}_{2}\right)$ in plants is essential for cell protection and cell signaling. Peroxidases (PRX) found in all plants and utilize either $\mathrm{H}_{2} \mathrm{O}_{2}$ or $\mathrm{O}_{2}$ to oxidize a wide variety of molecules (Yoshida 
et al., 2002). In addition, Ascorbate peroxidase (APX) and Glutathione reductase (GR) are found in almost every compartment of the plant cell and they participate in the removal of $\mathrm{H}_{2} \mathrm{O}_{2}$ (Mittler and Poulos, 2005; Liu et al., 2017).

Since heat waves and drought periods occur often simultaneously, it is good to know the response of plant varieties to both in stress conditions and in breeding procedure. Therefore, the purpose of the study is to investigate if there is a correlation between heat and drought tolerance of the cultivars as well as to determine the responses of the cultivars to drought stress. Besides some physiologic measurements, changes in activities of PRX, GR and APX were analyzed during drought and recovery in four strawberry cultivars that were indicated as heat-tolerant ('R. Hope' and 'Camarosa') and heat-sensitive ('Festival' and 'CG-3') in our previous work (Kesici et al., 2013).

\section{Materials and Methods}

\section{Biological material, drought and recovery}

Cold stored (frigo $=$ stored at $-2{ }^{\circ} \mathrm{C}$ until planting) seedlings of strawberry (Fragaria $\mathrm{x}$ ananassa cvs. 'Camarosa', 'CG-3', 'Festival' and 'R. Hope') were planted in $12 \mathrm{~cm}$ pots using perlite: torf: soil (1:1:1) mixture. Plants were grown for eight weeks (plants had five-six leaves) in a greenhouse with day/night mean temperature of $25 / 10^{\circ} \mathrm{C}$, average relative humidity of $70 \%$, photoperiod of $1 \mathrm{~h}$ and watered on need basis to avoid any water stress by Actagro (7- 7- 7) (Actagro LLC, Biola, CA, USA) nutrient solution. In order to compose drought condition, 10\% PEG 6000 (Poliethyleneglycol) was applied for 15 days. Meanwhile, control plants were watered regularly. Following the PEG treatments, plants were watered without PEG for 15 days to observe recovery. Parts of the leaves from each group of plants were then processed for determination of leaf RWC, loss of turgidity and cell membrane injury. Remaining leaves were right away frozen in liquid nitrogen and stored at -80 ${ }^{\circ} \mathrm{C}$ until used for proline and enzyme analyses.

\section{Leaf $R W C$ and loss of turgidity}

Leaf RWC and loss of turgidity (\%) were measured using the methods of Gulen and Eris (2003). For obtaining turgid weight, $2 \mathrm{~cm}$ leaf discs were floated on distilled water in a Petri dish for $4 \mathrm{~h}$ at room temperature. After incubation, leaf discs were removed from the Petri dish, surface-blotted, and immediately weighed. For oven drying, leaf discs were put in a new dry Petri dish with a lid and placed in an oven at $70{ }^{\circ} \mathrm{C}$ for $48 \mathrm{~h}$. After incubation leaf discs were weighed. Leaf RWC and loss of turgidity were measured as follow:

RWC $(\%)=[($ fresh weight-dry weight $) /($ turgid weight-dry weight $)] \times 100$;

Loss of turgidity $(\%)=[$ (turgid weight- fresh weight $) /$ turgid weight] $\times 100$.

\section{Cell membrane injury}

Cell membrane injury was determined by using the procedures of Arora et al. (1992) with some modifications (Kesici et al., 2013). Leaf discs $2 \mathrm{~cm}$ in diameter were cut from fullyexpanded, uniform leaves from each replicate per treatment. Discs were lightly rinsed in distilled water, gently blotted with paper, and placed in test tubes. Then, $20 \mathrm{~mL}$ of distilled water was added to each test tube. Samples were then vacuum infiltrated to allow uniform diffusion of electrolytes and incubated for $4 \mathrm{~h}$ at room temperature. After incubation, the electrical conductivity of each solution was measured using a conductivity meter. Leaf discs were then killed in the same solution by autoclaving, and total conductivity was measured at room temperature. Percentage injury at each temperature was calculated from ion leakage data using the equation:

$\%$ injury $=[(\% \mathrm{~L}(\mathrm{a})-\% \mathrm{~L}(\mathrm{c})) /(1-\% \mathrm{~L}(\mathrm{c}))]$ where \% $\mathrm{L}(\mathrm{a})$ and $\% \mathrm{~L}(\mathrm{c})$ were the percentage ion leakage for the applications and control samples, respectively.

\section{Proline content}

Proline content was determined according to the Bates et al. (1973) with the modifications for strawberry plant (Ergin et al., 2016). $0.5 \mathrm{~g}$ leaf samples were homogenized in $3 \%$ sulfosalicylic acid and centrifuged at $5000 \times \mathrm{g}$ at $4^{\circ} \mathrm{C}$ for $15 \mathrm{~min}$. The mixture was heated at $100^{\circ} \mathrm{C}$ for $1 \mathrm{~h}$ in a water bath after the addition of acid ninhydrin and glacial acetic acid. The reaction was then stopped by an ice bath. The mixture was extracted with toluene and the absorbance of the fraction with toluene aspired from the liquid phase was read at $520 \mathrm{~nm}$.

Proline concentration was determined by calibration curve and expressed as $\mu \mathrm{mol}$ proline $\mathrm{g}^{-1}$ fresh weight (FW). The concentration of proline was calculated using a proline standard curve $(0-1,000 \mu \mathrm{M})$ :

$[(\mu \mathrm{g}$ proline $/ \mathrm{ml} \times \mathrm{mL}$ toluene $) / 115.5 \mu \mathrm{g} / \mu$ mole $] /[(\mathrm{g}$ sample $/ 5]=\mu$ mole proline $/ \mathrm{g}$ of $\mathrm{FW}$;

$\mu$ mol proline $/ \mathrm{g} \mathrm{FW}=\left(\mathrm{A}_{520 \mathrm{~mm}} \times 1 \mathrm{~mL}\right.$ toluene $/ 115.5$ $\mu \mathrm{g} / \mathrm{mmol}$ ) g of FW.

\section{Analysis of antioxidant enzymes}

For APX and GR analysis, enzymes were extracted at $0-4{ }^{\circ} \mathrm{C}$ from $0.5 \mathrm{~g}$ of leaves, by grinding them with mortar and pestle in $1 \%$ polyvinylpyrrolidone 40 (PVP-40) and 2 $\mathrm{mL}$ of the following extraction solution (Turhan et al., 2008): for APX, $50 \mathrm{mM} \mathrm{K}-\mathrm{PO}_{4}$ buffer, $\mathrm{pH} 7.8,50 \mathrm{mM}$ ascorbate; for GR, 50 mM K-PO 4 , pH 7.6, 0.1 mM EDTA. APX activity was determined at $290 \mathrm{~nm}$, according to Nakano and Asada (1980). The concentration of oxidized ascorbate was calculated using the extinction coefficient $(£$ $\left.=2.8 \mathrm{mM}^{-1} \mathrm{~cm}^{-1}\right), 1 \mathrm{U}$ of APX and was defined as $\mu \mathrm{mol}$ $\mathrm{ml}^{-1}$ ascorbate oxidized per minute. GR activity was determined by following the oxidation of $\beta$-Nicotinamide adenine dinucleotide phosphate (NADPH) at $340 \mathrm{~nm}$ (extinction coefficient $6.2 \mathrm{mM}^{-1} \mathrm{~cm}^{-1}$ ) (Cakmak and Marschner 1992).

PRX was extracted from leaf tissues using the extraction methods described by Gulen et al. (2002). Discontinuous PAGE was performed for acidic and basic PRX, respectively, according to Davis (1964) and Reisfeld et al. (1962). The gel was stained for PRX using the method of Wendel and Weeden (1989). The relative distance (Rf value) of the bands on the gel was calculated as described by Manganaris and Alston (1992) using $\mathrm{Rf}=1.0$, distance to the fastest band and $\mathrm{Rf}=0.0$, the starting point. Bands were compared densitometrically by using the Public Domain $\mathrm{NIH}$ Image program (available on the internet at 
572

http://rsb.info.NIH.gov/nih-image/). Areas under the absorbance curve were expressed as arbitrary units.

\section{Statistics}

The experiment was arranged in a randomized block design. Two applications and three replicates were utilized. Data obtained were submitted to ANOVA, and the mean separation was accomplished by Duncan at $p<0.05$ (Table 1). All statistical analyses were carried out using the SPSS 22.0 software program.

\section{Results}

\section{Leaf RWC and loss of turgidity}

Leaf RWC of all cultivars changed depending on applications (Fig. 1). In all cultivars, RWC decreased with drought and increased with recovery. 'R. Hope' covered leaf RWC in drought with the value of $71.0 \%$. 'Camarosa', 'Festival' and 'CG-3' cultivars followed 'R. Hope' with 63.0, 58.0 and $53.0 \%$ of RWC, respectively. However, loss of turgidity in all cultivars was increased by the drought (Fig. 2). 'CG-3' showed the highest loss of turgidity ( 41.0\%) and 'R. Hope' (22.0\%) showed the lowest with the drought. Although turgidity loss decreased in all cultivars with recovery, 'Festival' kept the highest level. Two-way ANOVA revealed a significant effect of applications, cultivars and the interaction of applications and cultivars on RWC and loos of turgidity (Table 1).

\section{Cell membrane injury}

Cell membrane injury was measured by electrical conductivity in control, PEG applied and recovered plant leaves. PEG increased the percentage of cell membrane injury in the leaves of all cultivars (Fig. 3). In this sense, 'CG3 ' had the highest injury ( 70.0\%) while the 'R. Hope' had the lowest ( 2.0\%). However, after rewatering, cell membrane injury in recovered plants was almost at the same level with the control. Effects of drought and recovery on leaves also can be seen in Fig. 8. Two-way ANOVA revealed a significant effect of applications, cultivars and the interaction of applications and cultivars on cell membrane injury (Table 1).

\section{Proline content}

The change in the proline content was measured in control and treated plant leaves. The highest value of proline content (Fig. 4) was found in the PEG-treated cvs., 'R. Hope' (1,256.0 $\mu \mathrm{M} / \mathrm{gFW})$, 'Camarosa' $(1,023.0$ $\mu \mathrm{M} / \mathrm{gFW})$, 'CG-3' (648.0 $\mu \mathrm{M} / \mathrm{gFW})$ and 'Festival' (531.0 $\mu \mathrm{M} / \mathrm{gFW}$ ) respectively. In addition, proline content of heattolerant cultivars decreased with the recovery while it continued to increase in heat-sensitive cultivars. Two-way ANOVA revealed a significant effect of applications, cultivars and the interaction of applications and cultivars on proline content (Table 1).

\section{Activities of antioxidant enzymes}

In general, APX activity did not change significantly in control, PEG and recovery plants of 'CG-3' and 'Festival' (Fig. 5). The average APX activity of 'CG-3' was about 3.5 $\mu \mathrm{mol} / \mathrm{mg}$ protein while it was about $4.5 \mu \mathrm{mol} / \mathrm{mg}$ protein in 'Festival'. Similar results were observed in control and recovered plants of 'Camarosa' and 'R. Hope'. On the other hand, APX activity was markedly raised in plants exposed to PEG when compared to control and recovered plants of 'Camarosa' (7.0 $\mu \mathrm{mol} / \mathrm{mg}$ protein) and 'R. Hope' (10.0 $\mu \mathrm{mol} / \mathrm{mg}$ protein). GR activity of the PEG applied 'R. Hope' and 'Camarosa' plants significantly increased in comparison with the control plants (Fig. 6). On the other hand, GR activity of 'Festival' and 'CG-3' did not change significantly. While GR activity was 16.0 units $\mathrm{mg}$ protein $^{-1}$ in control plants, it drastically increased in PEG-treated 'Camarosa' plants (58.0 units/ mg protein). Similarly, while GR activity in control plants was 18.0 units $\mathrm{mg}$ protein $^{-1}$, it increased to 58.0 units $\mathrm{mg}$ protein ${ }^{-1}$ in PEG applied ' $\mathrm{R}$. Hope' plants. On the other hand, GR activity of cvs. 'Festival' and 'CG3' almost unchanged in control, PEG applied and recovered plants. Two-way ANOVA revealed a significant effect of applications, cultivars and the interaction of applications and cultivars on APX and GR activities (Table 1).

Native PAGE analysis of the samples was repeated at least three times with similar results. Thus, data from a single representative experiment are presented herein. Native PAGE profiles of isoperoxidases of control, PEG

Table 1. Analysis of variance (ANOVA) of applications (Apps), cultivar (Cvs.), and their interaction for leaf relative water content (RWC), loss of turgidity, cell membrane injury, proline content and, the activities of ascorbate peroxidase (APX) and glutathione reductase (GR)

\begin{tabular}{|c|c|c|c|}
\hline \multirow[t]{2}{*}{ Dependent variable } & \multicolumn{3}{|c|}{ Independent variable } \\
\hline & Apps. & Cvs. & Apps. $\times$ Cvs. \\
\hline RWC & 266.111 & 57.246 & 15.525 \\
\hline & $(P<0.001)$ & $(P<0.001)$ & $(P<0.001)$ \\
\hline \multirow[t]{2}{*}{ Loss of Turgidity } & 313.462 & 70.981 & 24.999 \\
\hline & $(P<0.001)$ & $(P<0.001)$ & $(P<0.001)$ \\
\hline \multirow[t]{2}{*}{ Cell Membrane Injury } & 951.068 & 446.660 & 408.165 \\
\hline & $(P<0.001)$ & $(P<0.001)$ & $(P<0.001)$ \\
\hline \multirow[t]{2}{*}{ Proline Content } & 643.033 & 51.538 & 161.573 \\
\hline & $(P<0.001)$ & $(P<0.001)$ & $(P<0.001)$ \\
\hline \multirow[t]{2}{*}{ APX activity } & 845.850 & 447.440 & 390.370 \\
\hline & $(P<0.001)$ & $(P<0.001)$ & $(P<0.001)$ \\
\hline \multirow[t]{2}{*}{ GR activity } & 1513.483 & 237.475 & 447.988 \\
\hline & $(P<0.001)$ & $(P<0.001)$ & $(P<0.001)$ \\
\hline
\end{tabular}




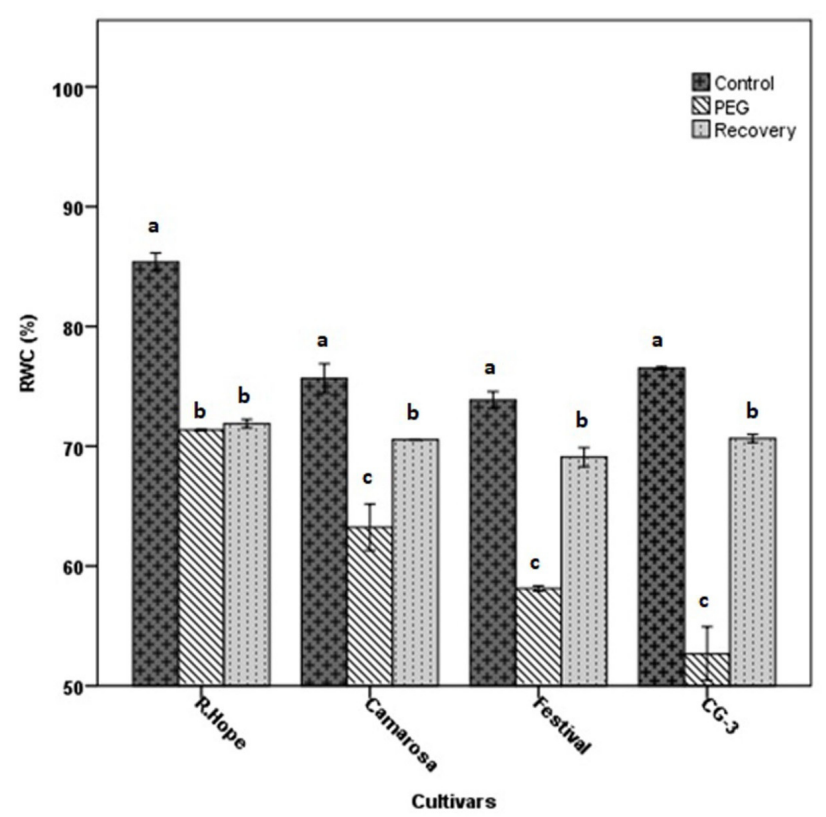

Fig. 1. Changes in leaf relative water content (RWC) of strawberry cultivars subjected to the drought by PEG application and recovered by rewatering application. The data are presented as the mean \pm S.E.M. (Standard Error of Means) of three replicates and significantly different $(\mathrm{P}<0.05)$ followed by different letters above the bars

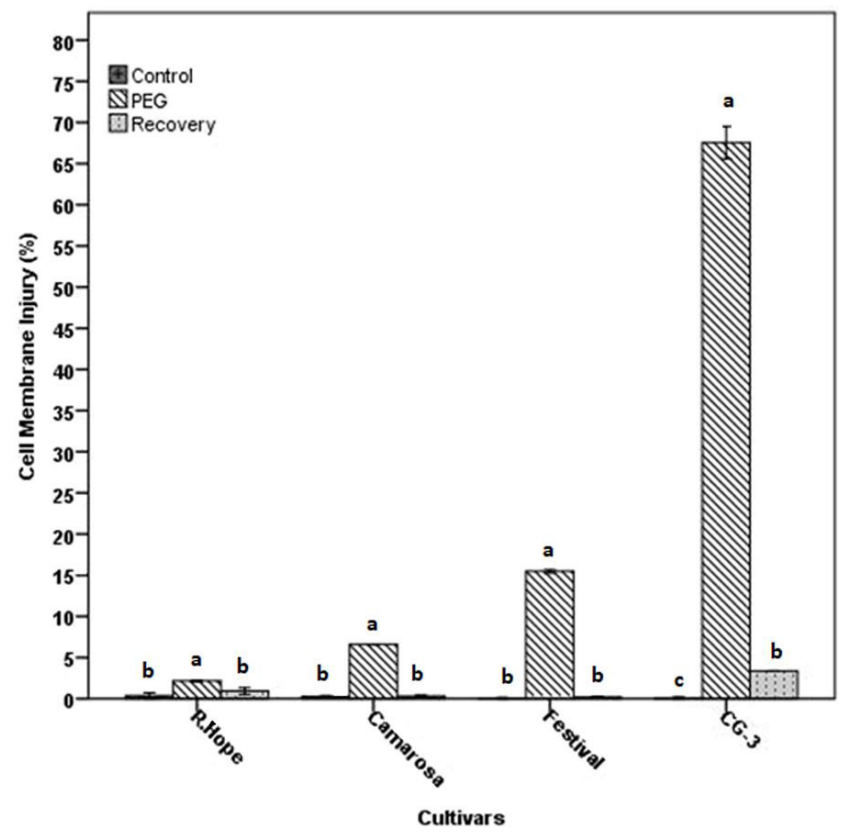

Fig. 3. Changes in cell membrane injury of strawberry cultivars subjected to the drought by PEG application and recovered by rewatering application. The data are presented as the mean \pm S.E.M. (Standard Error of Means) of three replicates and significantly different $(\mathrm{P}<0.05)$ followed by different letters above the bars

applied and recovered plants revealed predominantly basic isoperoxidases, whereas acidic isoperoxidases could not be observed. Native PAGE of basic PRX isozymes yielded three bands with $\mathrm{Rf}=0.45 \quad \mathrm{Rf}=0.55$ and $\mathrm{Rf}=0.60$

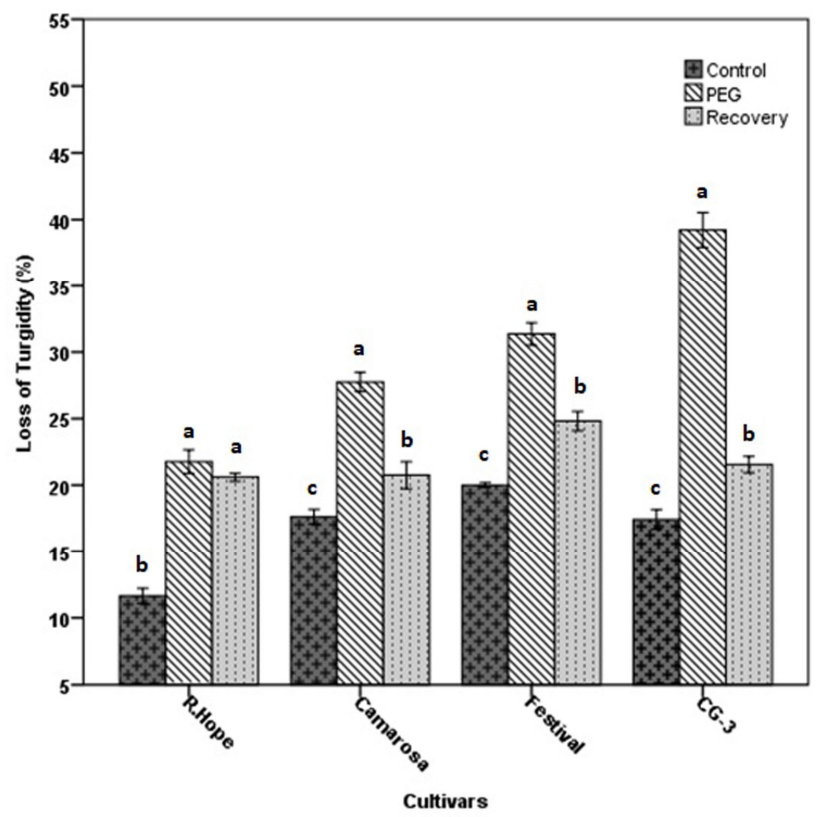

Fig. 2. Changes in loss of turgidity of strawberry cultivars subjected to the drought by PEG application and recovered by rewatering application. The data are presented as the mean \pm S.E.M. (Standard Error of Means) of three replicates and significantly different $(\mathrm{P}<0.05)$ followed by different letters above the bars

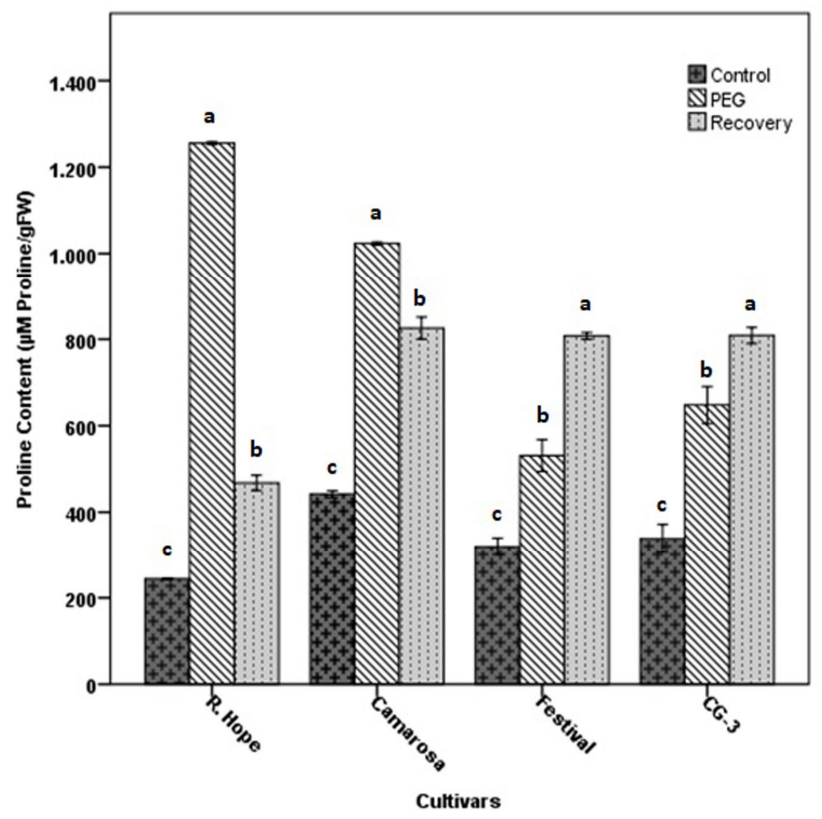

Fig. 4. Changes in proline content of strawberry cultivars subjected to the drought by PEG application and recovered by rewatering application. The data are presented as the mean \pm S.E.M. (Standard Error of Means) of three replicates and significantly different $(\mathrm{P}<0.05)$ followed by different letters above the bars

respectively (Fig. 7). Although basic PRX bands were faint and barely observed in control (unstressed) sample, the bands were observed commonly with different band intensities in the PEG application. Arbitrary values of bands 
574

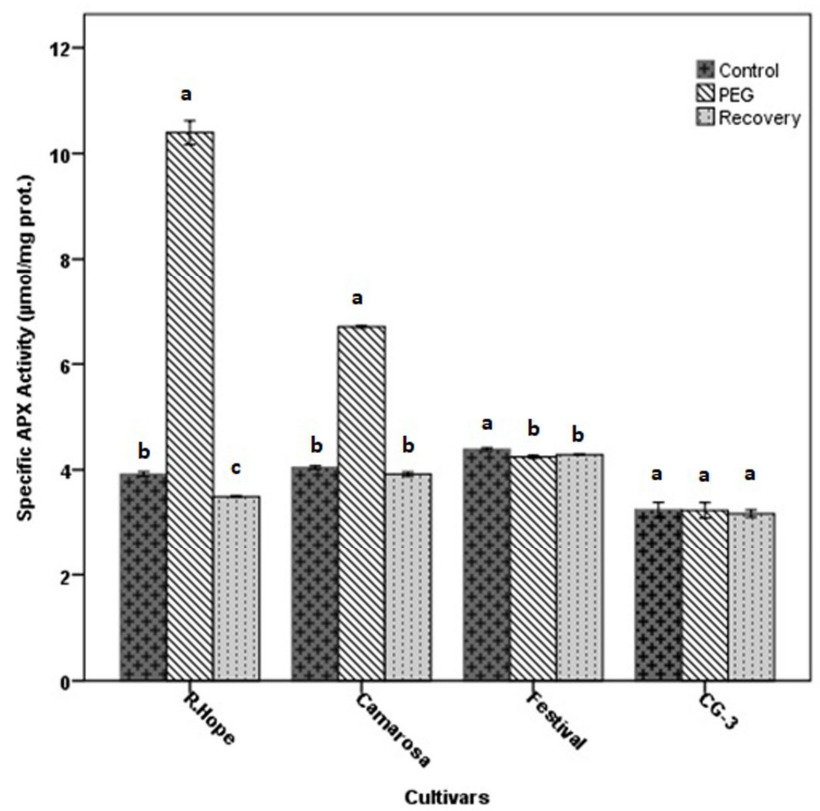

Fig. 5. Changes in ascorbate peroxidase (APX) activity of strawberry cultivars subjected to the drought by PEG application and recovered by rewatering application. The data are presented as the mean \pm S.E.M. (Standard Error of Means) of three replicates and significantly different $(P<0.05)$ followed by different letters above the bars

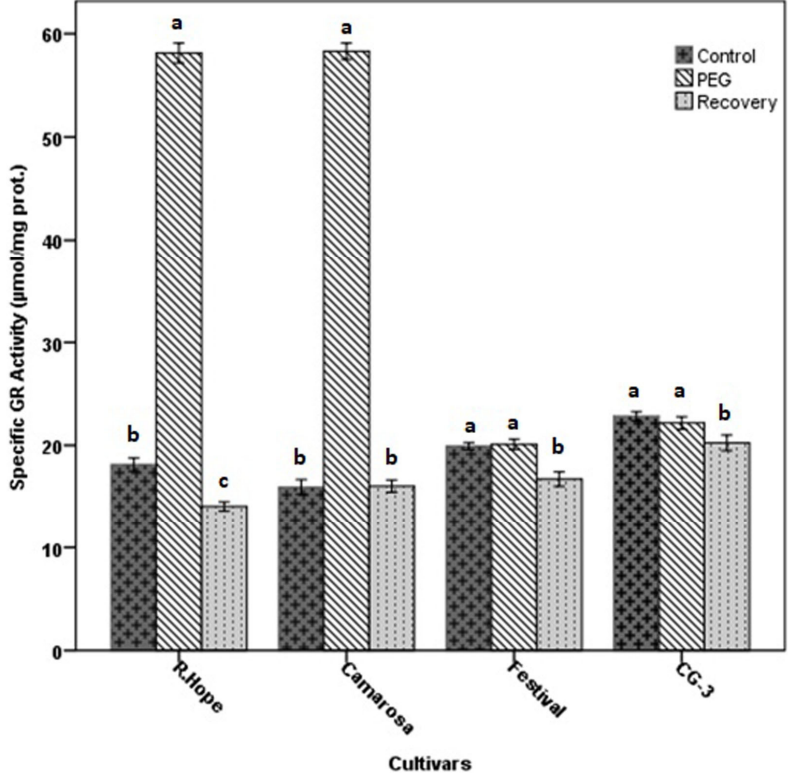

Fig. 6. Changes in glutathione reductase (GR) activity of strawberry cultivars subjected to the drought by PEG application and recovered by rewatering application. The data are presented as the mean \pm S.E.M. (Standard Error of Means) of three replicates and significantly different $(\mathrm{P}<0.05)$ followed by different letters above the bars
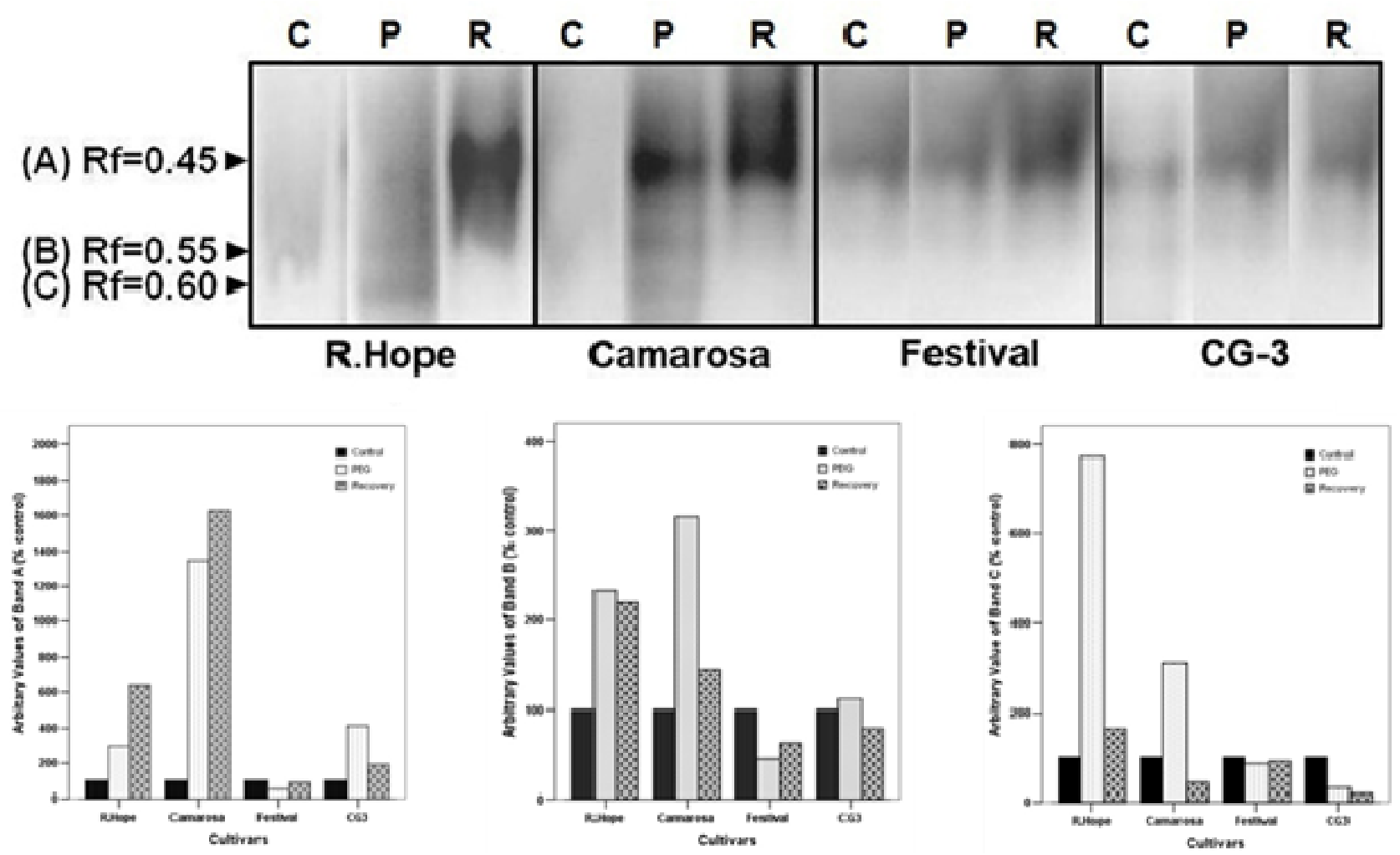

Fig. 7. Native PAGE of basic peroxidase (PRX) activities of the leaf tissue of four strawberry cultivars subjected to the drought by PEG application $(\mathrm{P})$, recovered by rewatering application $(\mathrm{R})$ and, unstressed (=control, $\mathrm{C})$. Arbitrary values of basic PRX bands present arbitrary values of $\mathrm{A}, \mathrm{B}$, and $\mathrm{C}$ according to control (\%) 


\section{Control}

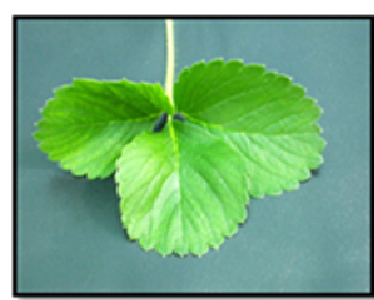

PEG

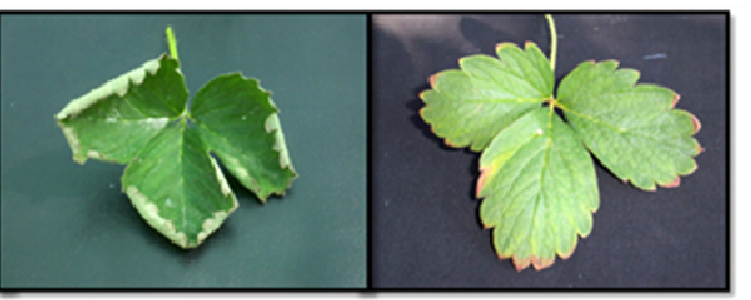

b)

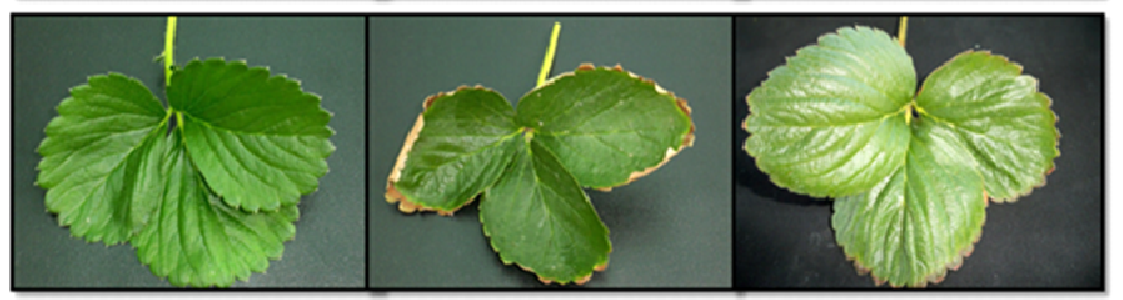

c)

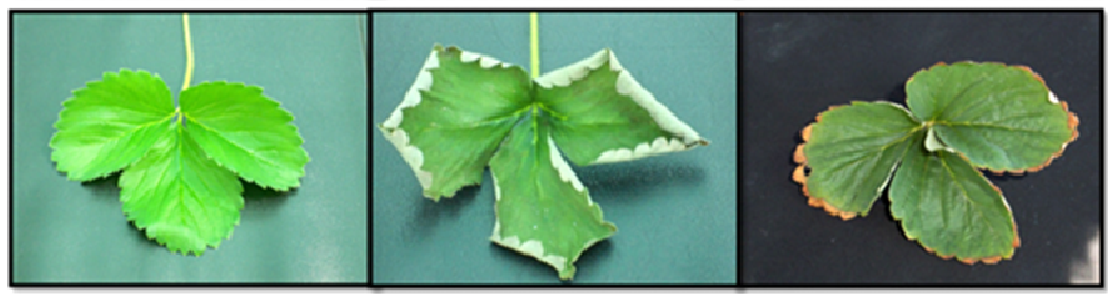

d)

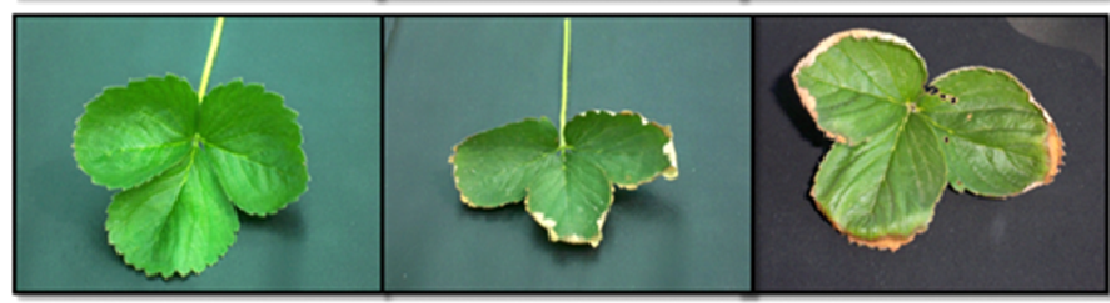

Fig. 8. The leaves of four strawberry cultivars, (a) 'Camarosa', (b) R. Hope, (c) Festival, (d) CG-3, in response to PEG induced drought and recovery applications. The leaves at left were from the plants watered throughout the experiment (unstressed, control); those in the middle were subjected to drought stress by PEG application before being watered again; those at right from the plants rewatered for 15 days (recovered)

vary among the cultivars and results showed that heattolerant cultivars ('R. Hope' and 'Camarosa') had more intensive PRX activity than sensitive cultivars ('Festival' and 'CG-3'). After recovery period band intensities decreased in bands $\mathrm{B}$ and $\mathrm{C}$ with Rf values 0.55 and 0.60 , respectively. However, in band A, PRX activity continued to increase especially in heat-tolerant cultivars.

\section{Discussion}

RWC and loss of turgidity are important characteristics that influence plant water relations under drought stress condition. Farooq et al. (2009) reported that droughttolerant species maintain water-use efficiency by reducing the water loss. Many studies showed that water-stressed plants had lower RWC and higher loss of turgidity than non-stressed ones (Siddique et al., 2001; Abbate et al., 2004; Efeoğlu et al., 2009; Vassileva et al., 2011). According to Vassileva et al. (2011), the down-regulation of physiological activities related to water conservation in stress-tolerant wheat varieties may improve the chances to survive, save resources and serve as a basis for rapid recovery after stress phase.

Even though many of the changes that appear during drought stress can be reversible by rehydration, irreversible changes can emerge till death if the stress is too great. Membranes are dynamic structures that support numerous biochemical and biophysical reactions. ROS are over synthesized and accumulated under stressed conditions and this cause an aggressive damage to the biological membranes and organic molecules (Anjum et al., 2017). Cell membrane stability on the measurement of cell membrane injury is a physiological index commonly used for the evaluation of stress tolerance and membrane stability of leaf tissues is shown as the most important parameter in the screening of drought tolerant genotypes (Dhanda et al., 2004). According to Gulen and Eriş (2003), ion leakage is an effective tool in measuring cell membrane thermostability and an indicator directly used in heat damage and in also heat-tolerant genotype screening (Kesici et al., 2013). A study of Bajji et al. (2002) on durum wheat showed that the drought sensitive cultivar 'Kabir 1' had a greater relative 
576

membrane injury. Stress tolerant genotypes like in durum wheat and tomato showed lower ion leakage than susceptible genotypes (Bajji et al., 2002; Roy et al., 2009). Such changes are frequently related to an increase in membrane permeability, affecting membrane integrity and cell compartmentation under stress conditions. Similarly, in present study heat-tolerant cvs. 'R. Hope' and 'Camarosa' had lower ion leakage than heat-sensitive cvs. 'Festival' and 'CG-3'.

In general, the synthesis and accumulation of osmolytes vary among plants species as well as among different cultivars of the same species under the different environment (Efeoglu et al., 2009). According to Bradford and Hsiao (1982), an extensive literature indicates that drought stress induces accumulation of proline. Increase in the free proline content suggests that proline is one of the common compatible osmolytes under water stress condition (Kumar et al., 2011; Anjum et al., 2017). Mohammadkhani and Heidari (2008) reported that the proline content of maize varieties 704 and 301 was elevated linearly with the increase of water deficit. Xiong et al. (2012) showed that drought stress induces a simultaneous accumulation of proline in rice. In peagonpea, severe progressive stress leads to about 25 -fold more accumulation of proline as compare to control (Kumar et al., 2011). In this study, proline content was increased in four cultivars by PEG application whereas it was decreased only in heat tolerant cvs. 'Camarosa' and 'R. Hope' by rehydration. However, proline content kept increasing linearly in heatsensitive cvs. 'Festival' and 'CG-3'.

It is known that ROS cause lipid peroxidation, and consequently membrane injuries, protein degradation and enzyme inactivation (Sariam et al., 2005). Therefore, plant cells need different mechanisms that will enable the detoxification of excess ROS and keep the formation and removal of ROS in balance (Kavas et al., 2013). The antioxidant enzymes are known as the most efficient mechanisms of oxidative stress and the enzymes in the ascorbate-glutathion cycle have an important role. Among these enzymes, APX and GR have the main role in plant methabolizm to cope with drought stress. Therefore, increased the enzyme activities are known to confer oxidative stress tolerance (Farooq et al., 2009).

APX is a central component of AsA-GSH cycle and plays an essential role in the control of intracellular ROS levels. GR, a $\mathrm{NAD}(\mathrm{P}) \mathrm{H}$-dependent enzyme, catalyzes the reduction of GSSG to GSH and, thus, maintains high cellular GSH/GSSG ratio (Sharma et al., 2012). In this study, APX and GR activity was increased markedly in PEG application in comparison to the control and recovery application of 'Camarosa' and 'R. Hope'. However, APX and GR activities of 'CG-3' and 'Festival' remained stable. These results are in a good agreement with the study by Sanchez-Rodriguez et al. (2010) and Wang et al. (2009) which found that enzyme activities of drought-tolerant varieties were found higher in tomato and alfalfa plants, respectively.

Native PAGE of PRX was performed to obtain acidic and basic isozyme profiles of leaf tissues subjected to the drought for various durations. Basic isoenzymes have been suggested that they might provide $\mathrm{H}_{2} \mathrm{O}_{2}$ for other peroxidases (Walter, 1992). According to Sharifi et al.
(2012) there's a strong negative correlation between cell membrane damage and activity of PRX enzyme in drought stress condition in wheat lines and it can be concluded that more activity of PRX enzyme in drought stress condition leads to increased cell membrane and chlorophyll stability, and it is related to the drought resistance of different lines. Moreover, Signorelli et al. (2013) compared two legume varieties and reported that higher tolerance to drought and/or heat was associated with concerted up-regulation of key detoxifying enzymes in several crop species/varieties leading to better ROS protection along with the stability of key metabolic processes like photosynthesis. In the present study, data from native PAGE indicated three basic isoperoxidases with different intensities according to applications. PRX activities were greater in heat-tolerant cvs. 'R. Hope' and 'Camarosa' especially in PEG and recovery applications. Thus, greater PRX activity indicated protection of cell membrane stability of heat-tolerant cultivars and contributed to the better recovery.

To summarize, in general during a drought, especially such a short-term drought as we did, plants may exhibit upward curling or rolling of leaves and/or yellowing and browning of leaves, particularly along leaf edges and tips. The recent study by Simova-Stoilova et al. (2016) reported the importance of the velocity and degree of recovery after the drought stress period. Moreover, Zwicke et al. (2015) indicated that the physiological activities level after a severe drought, recovery phase and the completeness of recovery are important for genotype comparison. As it was seen in Fig. 8, PEG-induced drought caused strawberry leaves to roll up and have a brown colour in all cultivars. Since the level of symptoms was vary among cultivars, it may be evaluated as an indication of tolerance of cultivars to drought. 'Camarosa' and 'R. Hope' showed better recovery performance after rewatering than 'Festival' and 'CG-3' having upward curling and brown colour along leaf edges of recovered plants. In conclusion, all data indicated that heattolerant cultivars showed relatively drought tolerance in this study. When the ion leakage results of 'Camarosa' and ' $R$. Hope' evaluated together with enzyme activities, it's thought that significant increase of the enzymes under drought and recovery application may protect the membranes and relatively improve the chances to survive.

\section{Acknowledgements}

The authors thank to Yaltır A.Ş. (Adana, Turkey) for supplying the strawberry seedlings used in the study.

\section{References}

Abbate PE, Dardanellib JL, Cantareroc MG, Maturanoc M, Melchiorid RJM, SueroaEE (2004). Climatic and water availability effects on wateruse efficiency in wheat. CropScience 44:474483.

Anjum SA, Ashraf U, Tanveer M, Khan I, Hussain S, Shahzad B,Zohaib A, Abbas F, Saleem MF, Ali I and Wang LC (2017). Drought induced changes in growth, osmolyte accumulation and antioxidant metabolism of three maizehybrids. Frontiers in PlantScience 8:69.

Arora R, Wisniewski ME, Scorza R (1992). Cold acclimation in genetically related (sibling) deciduous and evergreen peach (Prunus persica L. Batsch). I. Seasonal changes in cold hardiness and polypeptides of bark 
and xylem tissues. Plant Physiology 99:1562-1568.

Bajji M, Kinet JM, Lutts S (2002). The use of the electrolyte leakage method for assessing cell membrane stability as a water stress tolerance test in durum wheat. Plant Growth Regulation 36:61-70.

Bates LS, Waldren RP, Teare ID (1973). Rapid determination of free proline for water-stress studies. Plant and Soil 39:205-207.

Bradford KJ, Hsiao TC (1982). Physiological responses to moderate water stress. In: Lange OL, Nobel PS, Osmond CB, Ziegler H (Eds). Physiological Plant Ecology II. Water relations and carbon assimilation. Springer, Berlin 12B:263-342.

Cakmak I, Marschner H (1992). Magnesium deficiency and high light intensity enhance activities of superoxide dismutase, ascorbate peroxidase and glutathione reductase in bean leaves. Plant Physiology 98:12221227.

Davis BJ (1964). Disc electrophoresis. Method and application to human serum proteins. Annals of the NewYork Academy of Sciences 121:404 427.

Dhanda SS, Sethi GS, Behl RK (2004). Indices of drought tolerance in wheat genotypes at early stages of plant growth. Journal of Agronomy and CropScience 190:6-12.

Efeoğlu B, Ekmekçi Y, Çiçek N (2009). Physiological responses of three maize cultivars to drought stress and recovery. South African Journal of Botany $75(1): 34-42$.

Ergin S, Gülen H, Kesici M, Turhan E, İpek A, Köksal N (2016). Effects of high temperature stress on enzymatic and non-enzymatic antioxidants and proteins in strawberry plants. Turkish Journal of Agriculture and Forestry 40(6):908-917.

Farooq M, Wahid A, Kobayashi N, Fujita D, Basra SMA (2009). Plant drought stress: effects, mechanisms and management. Agronomy for Sustainable Development 29:185-212.

Grzesiak M, Filek M, Barbasz A, Kreczmer B, Hartikainen H (2013). Relationships between polyamines, ethylene, osmoprotectants and antioxidant enzymes activities in wheat seedlings after short-term PEGand NaCl-induced stresses. Plant Growth Regulation 69:177-189.

Gulen H, Arora R, Kuden A, Krebs SL, Postman J (2002). Peroxidase isozyme profiles in compatible and incompatible pear-quince graft combinations. Journal of the American Society for Horticultural Science 127:152-157.

Gulen H, Eris A (2003). Some physiological changes in strawberry (Fragaria $\times$ ananassa cv. 'Camarosa') plants under heat stress. Journal of Horticultural Science and Biotechnology 78:894898.

Gulen H, Eris A (2004). Effect of heat stress on peroxidase activity and total protein content in strawberry plants. Plant Science 166:739-744.

Gulen H, Cetinkaya C, Kadıogu M, Kesici M, Cansev A, Eris A (2008). Peroxidase activity and lipid peroxidation in strawberry (Fragaria $\times$ ananassa) plants under low temperature. Journal of Biology Environment and Science 2(6):95-100.

IPCC (2014). Climate change: Impacts, adaptation, and vulnerability. Part B: Regional aspects. Contribution of working group II to the fifth assessment report of the intergovernmental panel on climate change. Cambridge University Press: Cambridge, UK.

Jung S (2004). Variation in antioxidant metabolism of young and mature leaves of Arabidopsis thaliana subjected to drought. Plant Science
166:459-466.

Kavas M, Baloglu MC, Akca O, Kose FS, Gokcay D (2013). Effect of drought stress on oxidative damage and antioxidant enzyme activity in melon seedlings. Turkish Journal of Biology 37:491-498.

Kesici M, Gulen H, Ergin S, Turhan E, Ipek A, Koksal N (2013). Heat-stress tolerance of some strawberry (Fragaria $\times$ ananassa) cultivars. Notulae Botanicae Horti Agrobotanici Cluj-Napoca 41(1):238-243.

Kumar RR, Karajol K, Naik GR (2011). Effect of polyethylene gycol induced water stress on physiological and biochemical responses in Pigeonpea (Cajanus cajan L. Millsp.) Recent Research in Science and Technology3(1):148-152.

Liu C, Wang Y, Pan K, Wang Q, Liang J, Jin Y, Tariq A (2017). The synergistic responses of different photoprotective pathways in dwarf bamboo (Fargesia rufa) to drought and subsequent rewatering. Frontiers in Plant Science 8:489.

Manganaris AG, Alston FH (1992). Inheritance and linkage relationships of peroxidase isozymes in apple. Theoretical and Applied Genetics 83:392399.

MingDF, PeiZF, Naeem MS, Gong HJ,Zhou WJ (2012). Silicon alleviates PEG-induced water-deficit stress in upland rice seedlings by enhancing osmotic adjustment. Journal of Agronomy and Crop Science 198(1):14-26.

Mittler R, Poulos TL (2005). Ascorbate peroxidase: Antioxidants and reactive oxygen species in plants. Smirnoff N (Ed). Blacwell Publishing LtdUK.

Mohammadkhani N, Heidari R (2008). Drought-induced accumulation of soluble sugars and proline in two maize varieties. World Applied Sciences Journal 3(3):448-453.

Nakano Y, K Asada (1980). Spinach chloroplasts scavenge hydrogen peroxide on illumination. Plant and Cell Physiology 21:1295-1307.

Reddy A, Chaitanya KV, Vivekanandan M (2004). Drought-induced responses of photosynthesis and antioxidant metabolism in higher plant. Journal of Plant Physiology 161:1189-1202.

Reisfeld RA, Lewis UJ, Williams DE (1962). Disk electrophoresis of basic proteins and peptides on polyacrylamide gels. Nature 195:281-283.

Roy R, Agrawal V, Gupta SC (2009). Comparison of drought-induced polypeptides and ion leakage in three tomato cultivars. Biologia Plantarum 53(4):685-690.

Sairam RK, Srivastava GC, Agarwal S, Meena RC (2005). Differences in antioxidant activity in response to salinity stress in tolerant and susceptible wheat genotypes. Biologia Plantarum 49(1):85-91.

Sanchez-Rodriguez E, Rubio-Wilhelmi M, Cervilla LM, Blasco B, Rios JJ, Rosales MA, Romero L, RuizJM(2010). Genotypic differences in some physiological parameters symptomatic for oxidative stress under moderate drought in tomato plants. Plant Science 178:30-40.

Sharifi P, Amirnia R, Majidi E, Hadi H, Roustaii M, Nakhoda B, Alipoor HM, Moradi F (2012). Relationship between drought stress and some antioxidant enzymes with cell membrane and chlorophyll stability in wheat lines. African Journal of Microbiology Research 6(3):617-623.

Sharma P, Jha AB, Dubey RS, Pessarakli M (2012). Reactive oxygen species; oxidative damage and antioxidative defense mechanism in plants under stressful conditions. Journal of Botany 217037:1-26.

Siddique MRB, Hamid A, Islam MS (2001). Drought stress effects on water 
578

relations of wheat. Botanical Bulletin AcademiaSinica 41:35-39.

Signorelli S, Casaretto E, Sainz M, Diaz P, Monza J, Borsani O (2013). Antioxidant and photosystem II responses contribute to explain the drought - heat contrasting tolerance of two forage legumes. Plant Physiology and Biochemistry 70:195-203.

Simova-Stoilova L, Vassileva V, Feller U (2016). Selection and breeding of suitable crop genotypes for drought and heat periods in a changing climate: which morphological and physiological properties should be considered? Agriculture 6(2):26.

Srivalli B, Sharma G, Khanna-Chopra R (2003). Antioxidative defence system in upland rice cultivar subjected to increasing intensity of water stress followed by recovery. Physiologia Plantarum 119:503-512.

Turhan E, Gulen H, Eris A (2008). The activity of antioxidative enzymes in three strawberry cultivars related to salt-stress tolerance. Acta Physiologiae Plantarum 30:201-208.

Vassileva V, Signarbieux C, Anders I, Feller U (2011). Genotypic variation in drought stress response and subsequent recovery of wheat (Triticum aestivum L.). Journal of Plant Research 124:147-154.

Verslues PE, Bray EA (2006). Role of abscisic acid (ABA) and Arabidopsis thaliana $\mathrm{ABA}$-insensitive loci in low water potential-induced $\mathrm{ABA}$ and proline accumulation. Journal of Experimental Botany 57:201-212.

Walter MH (1992). Regulation of lignification in defense. In: Plant gene research - genes involved in plant defense. Boller T, Meins F (Eds). Springer-Verlagpp 329-352.
Wang W, Kim YH, LeeHS, Kim KY, DengXP, KwakSS (2009). Analysis of antioxidant enzyme activity during germination of alfalfa under salt and drought stresses. Plant Physiology and Biochemistry 47(7):570-577.

Wendel JF, Weeden NF (1989). Visualization and interpretation of plant isozymes. In: Isozymes in Plant Biology. Soltis DE, Soltis PS (Eds). Dioscorides Press, Portland, Oregon pp 5-44.

Xiong J, Zhang L, Fu G, Yang Y, Zhu C, Tao L (2012). Drought-induced proline accumulation is uninvolved with increased nitric oxide; which alleviates drought stress by decreasing transpiration in rice. Journal of Plant Research 125:155-164.

Xu Z, Zhou G, Shimizu H (2010). Plant responses to drought and rewatering. PlantSignaling and Behavior 5(6):649-654.

Yoshida K, Kaothien P, Matsui T, Kawaoka A, Shinmyo A (2002). Molecular biology and application of plant peroxidase genes. Applied Microbiology and Biotechnology 60:665-670.

Zwicke M, Picon-Cochard C, Morvan-Bertrand A, Prud'homme MP, Volaire $F(2015)$. What functional strategies drive drought survival and recovery of perennial species from upland grassland? Annals of Botany 116:1001-1015. 